\title{
Composition and Characterization of Foam Mat Dried Powder Prepared From Seedling and Cultivated Mango Cultivars of Himalayan Region
}

\author{
Namita Rani ${ }^{1}$, Anil Kumar Verma ${ }^{1 *}$, P.C. Sharma ${ }^{1}$, Raj Saini ${ }^{2}$ and Shivani ${ }^{1 *}$ \\ ${ }^{1}$ Department of Food Science and Technology, College of Horticulture \& Forestry, \\ Neri, Hamirpur, (HP) India \\ ${ }^{2}$ Department of Basics Sciences, College of Horticulture \& Forestry, \\ Neri, Hamirpur,(HP) India \\ *Corresponding author
}

Keywords

Mango cultivars,

Seedling mango,

CMC, Foam mat

drying, Mango

powder, Physico -

chemical properties

Article Info

Accepted:

05 April 2020

Available Online:

10 May 2020

\begin{abstract}
A B S T R A C T
Three cutivars of mango viz; Amrapali, Dashehari, Mallika and one seedling mango were evaluated for production of foam mat dried powder. Initially, physico-chemical properties were determined. Mango Pulp of different cultivars was foamed by carboxy -methyl - cellulose (CMC) at different concentrations $0,1.0$ and $2.0 \%$ followed by drying in tray drier for preparation of instant mango powder. Out of different concentrations, use of $2 \%$ carboxy methyl cellulose in each variety was found the most appropriate for foaming of mango pulp on the basis of foaming properties (foam density, foam expansion and foam stability), physico-chemical and sensory attributes . Among different cutivars, the yield of dried powder varied from $13.72-15.10 \%$. By using different concentrations of foaming agent, Dried mango powders contained 80.50-83.70 ${ }^{\circ} \mathrm{B}$ TSS, 0.94-1.53\% titratable acidity, 4.00-4.79 pH, 5.50-6.19\% moisture content, 4.50-4.65\% ash content, 40.95-48.62 \% reducing sugars, 73.99-80.05\% total sugars and 11.77 to $12.49 \mathrm{mg} / 100 \mathrm{~g}$ total carotenoids.
\end{abstract}

\section{Introduction}

Mango (Mangifera indica L.), also called as king of fruits, is the second important fruit crop of India after banana with an annual production of 21822.32 thousand metric tonnes from an area of 2258.13 thousand hectare (NHB, 2018). The major Mango producing states in India are Uttar Pradesh, Andhra Pradesh, Bihar, Karnataka and Tamil Nadu. Mango is one of the important indigenous fruit of our country belonging to the family Anacardiaceae and is known for its wide adaptability, high nutritive value, delicious taste, excellent flavor, attractive appearance and popularity among users 
(Barreto et al., 2008; Negi, 2000). In Himachal Pradesh, mango cultivation covered an area of 0.423 million hectare with an annual production of 0.436 million metric tonnes during the year 2018-19accounts for 8.80 and $18.23 \%$ of total production and area under fruit crops, respectively .Mangoes fruits are considered to have a good texture, flavor and high content of carotenoids, Vitamin C, phenolic compounds, minerals and fiber. Its consumption can provide antioxidants and is continuous intake in diet helps to prevent cardiovascular diseases and cancer (Danalache et al., 2015). Wide gap between total production and consumption, due to high perishability and susceptibility to mechanical damage during post harvest handling, poor transportation and storage facilities leads to post harvest losses (Mitra and Baldwin 1997). Jha et al., (2015) reported $6.92 \%$ losses during farm operations (harvesting, sorting, grading, and transportation) and $2.24 \%$ losses during storage channel in mango fruits.

Processing of fruit minimizes these losses to some extent and gives better returns to the farmers during glut seasons. Therefore, the conversion of ripe mango into processed products could be useful not only to reduce the post harvest losses but also retain nutritional quality in the processed products. Freshly harvested, ripe fruits which remain in good condition only for few days can be converted to commercial food commodities like pulp, juices, jam, nectars, etc by using various methods of processing (Ladole et al., 2014; Jori et al., 2013).

Among different techniques of processing, drying is the major food processing operation to increase the shelf life. The purpose of drying of fruit and vegetable juices is to produce a stable and easily handled form of the juice, which reconstitutes rapidly to a quality product resembling the original juice as closely as possible. The foam mat drying is one of the methods of dehydrating liquid foods in a very short period. Due to the porous structure of the foamed materials, mass transfer is enhanced leading to shorter dehydration times. This technique can be successfully employed for drying a variety of fruit juices and pulps. The dried powders have good reconstitution characteristics (Sharada, 2013). In foam mat drying process, dehydration is rapid, the colour and flavor are superior because of minimum heat-damage, the product is a free- flowing powder capable of instant rehydration in cold water and the process is achieved with a minimum cost (Rockwell et al., 1962).

The basic principle involved in the foam mat drying consists of conversion of liquid or semisolid material into stable foam by incorporating substantial volume of air or other non-toxic gases in the presence of a certain additives which works as foam inducer and stabilizer. The foam thus formed is spread on a mat in a thin layer and is exposed to a steam of hot air until it is dehydrated. The dehydrated product is conditioned and converted into powder (Srinivasan, 1996).

Besides cultivated varieties, the availability of Seedling mango fruits especially in low-hills of Himachal Pradesh is very high but, large quantity of such fruits goes waste during harvesting season. Therefore, development of product like instant mango powder can be an alternative for efficient utilization of Seedling mango as well as other varieties available in the area.

\section{Materials and Methods}

Fruits of three cultivars of mango viz. Amrapali, Dashehari and Mallika collected from Regional Horticulture and Forestory Research \& Training Centre Bhota and seedling mango from surrounding areas of the 
District Hamirpur in Himachal Pradesh were used for pulp extraction .Fully ripe and firm mango fruits after washing and peeling were cut into halves and passed through the pulper for extraction of pulp. The pulp was heated at $90^{\circ} \mathrm{C}$.and preserved with potassium metabisulphite $(2 \mathrm{~g} / \mathrm{kg}$ of pulp) in sterilized glass bottles for its later utilization for product development and analytical purposes.The pulp being thin and juicy was converted into stable foam by whipping the pulp in a blender for 5 min after addition of CMC @ 0-2\% followed by spreading the foam on stainless steel trays $\left(30 \times 20 \mathrm{~cm}^{2}\right.$, with a tray load of $150 \mathrm{~g}$ per tray) in a thin layer $(3-5 \mathrm{~mm})$ and dried in a mechanical dehydrator $\left(60 \pm 5^{\circ} \mathrm{C}\right)$ for about $4-8 \mathrm{~h}$. to a moisture content . The dried foam was scrapped from the trays and ground to a fine powder followed by packing in aluminum pouches and stored for further experimentation. The complete process for preparation of mango powder is given in figure 1 .

\section{Physical properties}

Fruit sizewas determined by using Vernier Caliper. Weight in grams was determined gravimetrically and expressed as mean weight (g). Pulp, peel and stone percentage were calculated based on the method adopted by Badhe et al., (2007).

\section{Chemical analysis}

The total soluble solids $\left({ }^{\circ} \mathrm{B}\right)$, titratable acidity, moisture content (\%), ascorbic acid (mg/100gm), total carotenoids (mg/100 mg), and ash content (\%) of papaya pulp and prepared powder were determined using standard analytical methods as per Ranganna (2014). The $\mathrm{pH}$ of the mango pulp and prepared powder (after dilution) was determined with the help of automatic $\mathrm{pH}$ meter (Deluxe $\mathrm{pH}$ meter model 101). Before estimation, the $\mathrm{pH}$ meter was calibrated with buffer solution of $\mathrm{pH} 4.0$ and $\mathrm{pH} 7.0$ (AOAC, 1995), while total and reducing sugars were determined by Lane and Eyon method as given by Ranganna (2014). Acidity was determined by titrating the aliquots against a standardized $0.1 \mathrm{~N} \mathrm{NaOH}$ solution to a pink end point using phenolphthalein as an indicator (Ranganna, 2014). The rate of dehydration per unit time was calculated by placing a weighed quantity of foamed pulp $(600 \mathrm{~g})$ on a stainless steel tray $\left(30 \times 20 \mathrm{~cm}^{2}\right)$ and drying in mechanical dehydrator $\left(60 \pm 5^{\circ} \mathrm{C}\right)$ to a constant moisture content $(w / w)$. The loss in weight during drying (\% dwb) was calculated by plotting the percent moisture on dry weight basis against time in hours (Ranganna, 2014)

\section{Foaming properties analysis}

The Foam density of foamed mango fruit pulp was determined by dividing the mass of the foam by its volume (Falade et al., 2003). Foam Density $\left(\mathrm{g} / \mathrm{cm}^{3}\right)=---{ }^{2}$ Mass of the foam, $\mathrm{g}$
Volume of the foam, $\mathrm{cm}^{3}$

Foam expansion was determined by using following equation (Akiokato et al., 1983).

Foam Expansion $(\%)=\frac{\mathrm{V}_{1}-\mathrm{V}_{0}}{--\cdot--\cdot---} \times 100$

Where, $\mathrm{V}_{0}$ is the initial volume of the mango pulp before foaming $\left(\mathrm{cm}^{3}\right)$ and $V_{1}$ is the final volume of the mango pulp after foaming $\left(\mathrm{cm}^{3}\right)$.

Foam stability was determined according to Marinova et al., (2009). The reduction of the foam volume was noted to be used as an index for the determination of the stability for every 30 minutes by using following relationship, 


$$
\text { Foam Stability }(\%)=\frac{\mathrm{V}_{0}}{\mathrm{~V}_{1}}
$$

Where, $\mathrm{V}_{0}$ is the final volume of the mango pulp after 2 hours of foaming and $V_{1}$ is the initial volume of the mango pulp after foaming

\section{Sensory microbiological and statistical analysis}

Ninepoints hedonic scale method as suggested by Amerine et al., (1965) was followed for conducting the sensory evaluation of foam mat dried papaya powder. Total plate count (TPC) was estimated by aseptically inoculating 0.1 gram of serially diluted sample (powder) in total plate count/standard plate count agar medium prepared according to Ranganna (2014). The data pertaining to sensory evaluation of papaya powder were analyzed according to Randomized Block Design (RBD) as described by Mahony (1985), while the data on physico-chemical characteristics of fruit, fruit pulp and instant powder were analyzed statistically by following Completely Randomized Design (CRD) of Cochran and Cox (1967).

\section{Results and Discussion}

\section{Physico- chemical characteristics of mango fruits}

Physical characteristics of Amrapali, Dashehari, Mallika and seedling mango are shown in Table-1. Mango cultivars showed highly significant differences in physical parameters Thelength and diameter in all the four cultivars of mango fruits varied from 5.80 to $11.35 \mathrm{~cm}$ and 4.71 to $7.10 \mathrm{~cm}$, respectively. This probably shows that highest and lowest being for Mallika and seedling mango respectively. Seedling mangoes were smallest in size with only 5.80 length and
$4.71 \mathrm{~cm}$ diameter. These values are in the same range as reported earlier (Mishra et al., 2014; Hada and Singh, 2018 and Bains and Dhilon, 1999).The weight of different cultivars of mango fruits varied between 80.18 to 350.02 g Chanana et al., (2005) also recorded higher fruit weight $(357.44 \mathrm{~g} /$ fruit) in cv. Mallika. According to Harshitha et al., (2016) average weight of mango fruits varied between 273 to 494 g. Further, Seedling mangoes are smaller in weight and size in comparison to improved cultivated varieties. Seeding mangoes are considered to possess thick peel and large stone in comparison to cultivated varieties. Accordingly, Seedling mangoes had highest percentage of peel $(21.00 \%)$ in comparison to other three varieties which showed the peel percentage in the range of 13.50 to $15.42 \%$ (Table 1). Vijayanand et al., (2015) recorded $14.8 \%$ peel content whereas Mishra et al., (2014) have recorded $10.67 \%$ peel percentage in Mallika. According to Gowda et al., (1995) peel content of different varieties of mango fruit varied between 13 to $21 \%$. Keeping in view the weight and size of fruits of different cultivars under study, the pulp recovery ranged between 69.21 to $76.30 \%$ in Dashehari, Amrapali and Mallika cultivars of mango. Mallika fruits gave the highest pulp (76.30 \%) while Seedling mangoes resulted in lowest pulp yield $(56.46 \%)$ in comparison to other varieties (Table 1). Our results are similar to the findings of Mishra et al., (2014) who have reported $73.68 \%$ pulp percentage in cv. Mallika whereas, Vijayanand et al., (2015) reported $75.3 \%$ pulp content in cv. Mallika. Xess et al., (2018) recorded 72.1g fruit weight in Amrapali. According to Harshitha et al., (2016) average pulp yield of mango fruits varied between 72.6 to $78.7 \%$. Seeding mangoes are considered to possess large stone in comparison to cultivated varieties. Accordingly, Seedling mangoes had highest percentage of stone $(22.54 \%)$ in comparison to other three varieties which 
showed the stone percentage in the range of 10.20 to $16.49 \%$ (Table 1). Vijayanand et al., (2015) reported $10.7 \%$ seed content in Mallika and $11.88 \%$ in cv. Amrapali by Hossain et al., (2001).It is evident from Table 1 that the colour appearance of Amrapali and Seedling mango fruit was green whereas Mallika and Dashehari fruit had yellowish green colour. Ara et al., (2014) has also observed green colour in Amrapali cultivar fruits whereas cv. Mallika fruit had yellowish green colour.

\section{Chemical characteristics}

\section{Total soluble solids}

A perusal of data in Table 2 indicates that total soluble solids among different cultivars of mango fruits varied from $13.26^{\circ} \mathrm{B}$ to 16.05 ${ }^{\circ} \mathrm{B}$. Maximum total soluble solids were recorded in cv. Amrapali $\left(16.05{ }^{\circ} \mathrm{B}\right)$ and minimum in Seedling mango $\left(13.26^{\circ} \mathrm{B}\right)$. Ara et al., (2014) has reported $20.55 \%$ and 11.87 $\%$ TSS in Amrapali and Mallika varieties of mango, respectively.

\section{Titratable acidity}

Titratable acidity among different cultivars of mango fruits varied from $0.14 \%$ to $0.31 \%$ (Table 2). Maximum titratable acidity of the fruit was recorded in Seeding mango $(0.31 \%)$ and minimum in cv. Dashehari (0.14\%). These results are on the similar lines obtained by Singh et al., (1976) and Xess et al., (2018). Safdar et al., (2012) observed wide variation in the titratable acidity of different cultivars of mango which is attributed to their inherent characteristics and ripening stages.

\section{pH}

It is evident from Table 2 that mean $\mathrm{pH}$ among different cultivars ranged from 3.82 to 4.44. Maximum $\mathrm{pH}$ was recorded in $\mathrm{cv}$.
Amrapali as 4.44 and minimum in Seedling mango (3.82). These results are in conformity with the findings of Xesset al., (2018) who observed $\mathrm{pH}$ as 3.75 in Totapuri and 4.32 in Amrapali and Vijayanand et al., (2015) observed that $\mathrm{pH}$ of Mallika cultivar was 4.0.

\section{Ascorbic acid}

Perusal of data in the Table 2 shows that Seedling mangoes possessed highest ascorbic acid content $(30.12 \mathrm{mg} / 100 \mathrm{ml})$ in comparison to other three varieties which showed ascorbic acid content in the range of 16.58 in Dashehari to $20.78 \mathrm{mg} / 100 \mathrm{ml}$ in Amrapali. Mishra et al., (2014) has observed highest ascorbic acid in cv. Amrapali $(21.0 \mathrm{mg} / 100 \mathrm{~g}$ ) followed by Mallika (20.0 mg/ 100g) and Dashehari (19.5 mg/ 100g).

\section{Total carotenoids}

Data given in Table 2 shows thattotal carotenoids among different cultivars of mango fruits ranged from $1.57 \mathrm{mg} / 100 \mathrm{ml}$ to $2.91 \mathrm{mg} / 100 \mathrm{ml}$. Maximum total carotenoids were recorded in cv. Dashehari (2.91 $\mathrm{mg} / 100 \mathrm{ml}$ ) while Seedling mango exhibited comparatively lower carotenoids (1.57 $\mathrm{mg} / 100 \mathrm{ml}$ ). Mishra et al., (2014) reported highest beta carotene in cultivar Amrapali (5.4 mg/100gm) followed by Mallika (5.3 $\mathrm{mg} / 100 \mathrm{~g})$ and Dashehari (3.7mg/100g).

\section{Reducing sugars}

Perusal of data mentioned in the Table 2 shows that reducing sugars of different cultivars of mango fruits varied from $5.06 \%$ to $6.14 \%$. Maximum reducing sugars were recorded in cv. Amrapali as $6.14 \%$, and minimum in Seedling mangoes (5.06 \%). Mishra et al., (2014) reported higher reducing sugar in cv. Mallika (6.2 \%) followed by Amrapali (6.1 \%) and Dashehari (5.0 \%) whereas lower reducing sugar have been 
reported by Sharma etal., (1999) as $3.87 \%$ in cv. Dashehari, and in cv. Langra and Mallika as $3.95 \%$ and $3.00 \%$ respectively, by Chanana et al., (2005).

\section{Total sugars}

It is evident from Table 2 that total sugars ranged from 12.42 to $15.03 \%$ in different cultivars of mango fruits. Highest total sugars were observed in cv. Amrapali (15.03 \%) followed by Mallika and Dashehari whereas Seedling mango contained comparatively lowest total sugars (12.42\%). Mishra et al., (2014) reported highest total sugar in cv. Mallika (18.5\%) followed by Amrapali (17.0 $\%)$ and Dashehari (15.2 \%). According to Shafique et al., (2006) ripe stage had higher sugar content as compared to immature and mature stages in mango fruits.

\section{Effect of carboxy methyl cellulose concentrations on foaming characteristics of pulp of different cultivars of mango}

Carboxy methyl cellulose concentrations significantly affected the foaming characteristics.

Results of foam density, foam expansion and foam stability of the mango cultivarsare shown in Figure 2, 3 and 4 . An increase in Carboxy methyl cellulose concentration resulted in an increase in foam expansion ,foam stability and a decrease in foam density in all cultivars used in this study. As expected foam prepared by using $2 \% \mathrm{CMC}$ had the lowest foam density and maximum foam expansion and foam stability in among different cultivars of mango pulp .Mango pulp foams of different cultivars with a higher concentration of carboxy methylcellulose (lower density) exhibited higher stability or lower amount of liquid released from the foam than foams with a lower concentration of carboxy methylcellulose with higher density. This is because carboxy methyl cellulose reduces surface tension and interfacial tension in an aqueous system. Furthermore, it encourages the formation of a strong film and stabilizes the interfacial film of the foam system mango pulp foam samples containing higher amount of carboxy methylcellulose, therefore exhibited lower density, higher expansion and higher stability. The results of current study are in agreement with the work of Rajkumar et al., (2007) who reported that as the concentrations of egg albumin (5 to 15\%), the foam density of mango pulp decreased from $0.60 \mathrm{~g} / \mathrm{cm}^{3}$ to $0.51 \mathrm{~g} / \mathrm{cm}^{3}$. Among different cultivars of mango fruit, the mean foam expansion was recorded highest in cv. Amrapali $(17.50 \%)$ whereas minimum in Seedling mango (10.82 $\%$ ). However, the interaction between cultivars and different concentrations of foaming agent significantly varied from 2.47 $\%$ to $27.51 \%$. Earlier Rajkumar and Kailappan (2006) recorded 70.5-101.2 per cent foam expansion in Totapuri mango pulp. It is evident from Figure 3 that among different concentrations of foaming agent, the mean foam stability was recorded maximum (100\%) in mango pulps which was treated with 2\% CMC. Whereas, pulps whipped without using foaming agent (control) did not show any foam stability. Further, the foam stability increased with an increase in foaming agent concentration. Among different cultivars of mango fruit, the mean foam stability ranged between 66.27 to 66.64 $\%$ which is considered a desirable attribute. However, interaction between cultivars and foaming agent concentrations was found to be significant which ranged between 0 to $100 \%$. The maximum foam stability was recorded in a treatment combination of different cultivars and different concentration of foaming agent in all the cultivars $(100 \%)$ with $2 \%$ CMC while using $1 \% \mathrm{CMC}$ the foam stability was slightly lower. Similar findings have been reported by Rajkumar and Kailappan (2006) 
in Totapuri mango pulp with foam stability 96.4-98.2 \% and Affandi et al., (2017) in Nigella sativa beverage ranging from 71.00 $100.00 \%$, respectively.

\section{Drying time}

Data presented in Table 3 reveal that among different concentrations of foaming agent, the mango pulps foam obtained without CMC (control) took longer time $(8.48 \mathrm{hrs})$ for drying as compared to the foam which was prepared by using $2 \% \mathrm{CMC}$ which took only $7.67 \mathrm{hrs}$. for drying to desired moisture content. It was observed that the drying time of mango pulps of all cultivars decreased when the concentration of foaming agent was increased. Among different cultivars of mango fruit, the mean maximum drying time was taken by foam of mango pulp of cv. Mallika (8.54 hrs) followed by Seedling mango (7.97 hrs), Amrapali (7.90 hrs.) and Dashehari (7.75 hrs). However, the interaction between cultivars of mango fruits and different concentrations of foaming agent significantly varied from 7.45 to $9.02 \mathrm{hrs}$. Kandasamy et al., (2014) reported that drying time required for foamed papaya pulp was lower than non-foamed pulp at all selected temperatures. Sharma et al., (2002) also found that juice concentrate of $45{ }^{\circ}$ Brix with $2-3 \%$ $\mathrm{CMC}$ to a moisture content of about $5 \%$ took $10 \mathrm{hrs}$ whereas juice concentrate of different folds without addition of stabilizer took 13.50 to $20.30 \mathrm{hrs}$ for drying.

Effect of CMC concentrations on physicochemical properties of foam mat dried mango pulp

A perusal of data in Table 4 indicates that among different concentration of foaming agent, the mean highest powder yield was recorded $(14.84 \%)$ in mango pulps which were treated with $2 \% \mathrm{CMC}$ and minimum by control treatment with a yield $(14.53 \%)$. It was observed that powder yield percentage increased with the increase in foaming agent concentration. Among different cultivars of mango fruit, the mean powder yield was recorded maximum in cv. Mallika (14.96\%) whereas minimum powder yield percentage was found in Seedling mango (13.93\%). However, interaction between cultivars and foaming agent concentration was found to be significant which ranged between 13.72 and $15.10 \%$. Similar results are reported by Sharma et al., (2002) in foam mat dried hill lemon powder which was increased with increase in concentration of foaming agent.

\section{Total soluble solids (TSS)}

The data pertaining to total soluble solids of mango powder of different cultivars presented in Table 5 reveal that among different concentrations of foaming agent, the mean total soluble solids ranged between $81.63{ }^{\circ} \mathrm{B}$ to $82.28{ }^{\circ} \mathrm{B}$. It was observed that total soluble solids increased with the increase in foaming agent concentration. Among different cultivars of mango, the mean total soluble solids were recorded maximum in cv. Amrapali powder $\left(83.36{ }^{\circ} \mathrm{B}\right)$ whereas minimum in Seedling mango powder $(80.76$ $\left.{ }^{\circ} \mathrm{B}\right)$. However, interaction between cultivars and foaming agent concentrations was found to be significant and varied from $80.50{ }^{\circ} \mathrm{B}$ to 83.70 ${ }^{\circ}$ B. Shaari et al., (2017) also observed similar increasing trend in total soluble solids $\left(7.33-8.10^{\circ} \mathrm{B}\right)$ with increase in foaming agent (egg albumen) concentrations (0-20\%) and in TSS $\left(94.05-94.97^{\circ} \mathrm{B}\right)$ of foam mat dried hill lemon juice powder prepared by using different levels of juice concentrates (0 to $\left.45^{\circ} \mathrm{B}\right)$ with CMC (1-3\%) by Sharma et al., (2002).

\section{pH}

Data presented in Table 5 show that among different concentrations of foaming agent, the mean maximum $\mathrm{pH}$ was recorded a maximum of (4.58) in mango pulps treated with $2 \%$ 
CMC and minimum (4.51) in control treatments. Among different cultivars of mango fruit, the mean maximum $\mathrm{pH}$ was recorded in cv. Mallika (4.75) while minimum was recorded in Seedling mango (4.05). Among different cultivars and foaming agent concentrations the $\mathrm{pH}$ of the powder ranged between 4.00 and 4.79 . The difference in $\mathrm{pH}$ value of different varieties might be attributed to the presence of inherent acidity in the represented pulps. However, interaction between cultivars and foaming agent concentrations was found to be non significant. Gradual increase in $\mathrm{pH}$ (3.994.54) in foam mat dried pineapple fruit has also been reported by Shaari et al., (2017).

\section{Titratable acidity (\%)}

A perusal of data in Table 5 indicates that among different concentrations of foaming agent $(0-2 \%)$, the mean titratable acidity in mango powders ranged between 1.05 to 1.26 $\%$ as citric acid. It was observed that titratable acidity decreased with an increase in foaming agent concentration. Among different cultivars of mango fruit, the mean titratable acidity of mango powders was recorded maximum in Seedling mango (1.38 \%) whereas minimum titratable acidity percentage was found in cv. Amrapali (1.03 $\%)$. With respect to interaction between among different cultivars and foaming agent concentrations, the titratable acidity ranged between $0.94 \%$ to $1.53 \%$ and found to be significant. Similar trend in titratable acidity 0.279-0.557 per cent in mandarin powder has been reported by Kadam et al., (2011) and 57.69-44.06 per cent in hill lemon juice powder by Sharma et al., (2002).

\section{Moisture content (\%)}

Data presented in Table 6 show the effect of different concentrations of foaming agent (carboxy methyl cellulose) on moisture content of mango powder of different cultivars. The data reveal that among different concentration of foaming agent, the mean moisture content ranged between 5.57 to 6.08 $\%$. Among different cultivars of mango fruit, the mean moisture content of the powder was recorded maximum in cv. Mallika (5.93 \%) followed by cv. Amrapali (5.74 \%). However, interaction between cultivars and foaming agent concentration was found to be non significant. The maximum moisture was observed in cv. Mallika powder $(6.19 \%)$ without $\mathrm{CMC}$ and the minimum moisture content was observed in cv. Amrapali powder $(5.50 \%)$ treated with $2 \%$ CMC. As the foaming of pulp by addition of $2 \% \mathrm{CMC}$ helped in better removal of moisture during drying. Similar to these findings Shaari et al., (2017) recorded 3.91 to 7.91 per cent moisture in pineapple powder and Sharma et al., (2004) reported 5.95-5.65 per cent moisture content in hill lemon juice powder.

\section{Ash content (\%)}

The data pertaining to ash content of mango powder of different cultivars presented in Table 6 reveal that among different concentrations of foaming agent, the mean ash content was found to be $4.61 \%$ in treatments treated with $2 \% \mathrm{CMC}$ and $4.55 \%$ in control treatments of all cultivars. It was observed that the ash content was increased with an increase in concentration of foaming agent. Among different cultivars of mango, the mean ash content was recorded maximum in cv. Amrapali powder $(4.62 \%)$ whereas minimum was found in Seedling mango powder $(4.52 \%)$. Among different cultivars and concentration of foaming agent, the ash content in powders varied between $4.50 \%$ and $4.65 \%$. Earlier, Patil et al., (2014) has reported opposite trend in ash content (1.5-3.3 per cent) with subsequent increase in maltodextrin foaming agent concentration (7-12 per cent) in guava powder. 


\section{Total carotenoids}

Aperusal of data in Table 6 indicate that among different concentrations of foaming agent, the mean total carotenoids was recorded a maximum $(12.29 \mathrm{mg} / 100 \mathrm{~g})$ in mango powders without $\mathrm{CMC}$ and a minimum of $(11.88 \mathrm{mg} / 100 \mathrm{~g})$ in mango powders treated with $2 \%$ CMC. It was observed that total carotenoids decreased with an increase in foaming agent concentrations, as $\mathrm{CMC}$ is much does not contain carotenoids. Among different cultivars of mango fruit, total carotenoids ranged between 11.93 to $12.22 \mathrm{mg} / 100 \mathrm{~g}$. However, the interaction between cultivars and foaming agent concentration was found to be significant. The maximum total carotenoids were recorded in cv. Mallika powder (12.49 $\mathrm{mg} / 100 \mathrm{~g}$ ) without CMC whereas the minimum total carotenoids $(11.77 \mathrm{mg} / 100 \mathrm{~g})$ were recorded in Seedling mango powder treated with $2 \%$ CMC. Similar trend of decline in total carotenoids was observed by Wilson et al., (2012) in mango powder $(16.59-4.25 \mathrm{mg} / 100 \mathrm{~g})$ and Khamjae and Rojanakorn (2018) in passion fruit (83.87$72.51 \mathrm{mg} / 100 \mathrm{~g}$ ).

\section{Ascorbic acid}

Data presented in Table 7 reveal that ascorbic acid content among different concentrations of foaming agent was recorded maximum as $27.27 \mathrm{mg} / 100 \mathrm{~g}$ in control treatment (without $\mathrm{CMC})$ and minimum of $(27.06 \mathrm{mg} / 100 \mathrm{~g})$ with $2 \%$ CMC. It was found that ascorbic acid content decreased with the increase in foaming agent concentration. Among different cultivars of mango fruit, the mean ascorbic acid content was recorded maximum in Seedling mango powder $(35.27 \mathrm{mg} / 100 \mathrm{~g})$ while minimum in cv. Dashehari powder $(23.73 \mathrm{mg} / 100 \mathrm{~g})$. As such Seedling mango powder was considered good source of vitamin C. However, interaction between cultivars and foaming agent concentration was found to be significant and ranged between $23.62 \mathrm{mg} / 100 \mathrm{~g}$ to $35.36 \mathrm{mg} / 100 \mathrm{~g}$. Similar trend of reduction in ascorbic acid content has been recorded in foam mat dried hill lemon juice powder by Sharma et al., (2004).

\section{Reducing sugar (\%)}

The data pertaining to reducing sugar of mango powders of different cultivars presented in Table7 reveal that among different concentrations of foaming agent, the mean reducing sugar ranged between 43.80 to $45.62 \%$ in different concentrations of CMC. It was observed that the reducing sugar increased with an increase in concentrations of foaming agent. Among different cultivars of mango, the mean reducing sugar was recorded maximum in cv. Amrapali powder $(47.94 \%)$ whereas minimum in Seedling mango powder (41.71 \%). However, interaction between cultivars and foaming agent concentrations was found to be significant for the reducing sugar which varied from $40.95 \%$ to $48.62 \%$. Earlier Akhtar et al., (2010) has also reported increase in reducing sugars $1.40-9.3$ per cent from juice to mango juice powder.

\section{Total sugar $(\%)$}

A perusal of data in Table 7 indicates that among different concentrations of foaming agent, the mean total sugar was recorded a maximum of $79.30 \%$ in mango powders prepared by using $2 \% \mathrm{CMC}$ and minimum (75.83 \%) in mango powders without CMC. It was observed that total sugar increased with an increase in foaming agent concentrations. Among different cultivars of mango fruit, the mean total sugar was recorded maximum in cv. Amrapali powder $(78.82 \%)$ and minimum in Seedling mango powder (75.74 \%). However, interaction between cultivars and foaming agent concentration was found to be significant for total sugar of mango powders ranging between 73.99 to $80.05 \%$. 
Table.1 Physical characteristics of different cultivars of mango fruit

\begin{tabular}{|c|c|c|c|c|c|c|c|}
\hline Cultivars & $\begin{array}{l}\text { Fruit } \\
\text { weight } \\
\text { (gm) }\end{array}$ & $\begin{array}{l}\text { Fruit } \\
\text { length } \\
\text { (cm) }\end{array}$ & $\begin{array}{l}\text { Fruit } \\
\text { diameter } \\
(\mathbf{c m})\end{array}$ & $\begin{array}{l}\text { Peel } \\
(\%)\end{array}$ & $\begin{array}{c}\text { Pulp } \\
(\%)\end{array}$ & $\begin{array}{c}\text { Stone } \\
(\%)\end{array}$ & Colour \\
\hline Amrapali & $188.20 \pm 1.11$ & $9.40 \pm 0.13$ & $4.73 \pm 0.04$ & $15.42 \pm 0.10$ & $71.37 \pm 0.015$ & $13.25 \pm 0.21$ & Green \\
\hline Dashehari & $118.44 \pm 0.22$ & $8.47 \pm 0.04$ & $5.52 \pm 0.01$ & $14.30 \pm 0.03$ & $69.21 \pm 0.17$ & $16.49 \pm 0.56$ & Yellowish Green \\
\hline Mallika & $350.02 \pm 0.98$ & $11.35 \pm 0.14$ & $7.10 \pm 0.04$ & $13.50 \pm 0.19$ & $76.30 \pm 0.27$ & $10.20 \pm 0.12$ & Yellowish Green \\
\hline Seedling mango & $80.18 \pm 0.35$ & $5.80 \pm 0.12$ & $4.71 \pm 0.03$ & $21.00 \pm 0.19$ & $56.46 \pm 0.34$ & $22.54 \pm 0.33$ & Green \\
\hline $\mathrm{CD}_{0.05}$ & 2.332 & 0.363 & 0.094 & 0.451 & 0.758 & 1.060 & \\
\hline
\end{tabular}

Table.2 Chemical characteristics of mango pulp of different cultivars

\begin{tabular}{|c|c|c|c|c|c|c|c|}
\hline Cultivars & $\begin{array}{c}\text { TSS } \\
\left({ }^{\mathbf{0}} \text { Brix }\right)\end{array}$ & pH & $\begin{array}{c}\text { Titratable } \\
\text { acidity } \\
\text { (\% citric acid })\end{array}$ & $\begin{array}{c}\text { Ascorbic acid } \\
(\mathbf{m g} / 100 \mathrm{ml})\end{array}$ & $\begin{array}{c}\text { Total } \\
\text { Carotenoids } \\
(\mathbf{m g} / \mathbf{1 0 0} \mathbf{~ m l})\end{array}$ & $\begin{array}{c}\text { Reducing } \\
\text { sugar } \\
(\%)\end{array}$ & $\begin{array}{c}\text { Total sugar } \\
(\%)\end{array}$ \\
\hline Amrapali & $16.05 \pm 0.02$ & $4.44 \pm 0.01$ & $0.15 \pm 0.003$ & $20.78 \pm 0.04$ & $1.93 \pm 0.01$ & $6.14 \pm 0.02$ & $15.03 \pm 0.09$ \\
\hline Dashehari & $15.00 \pm 0.05$ & $4.42 \pm 0.01$ & $0.14 \pm 0.003$ & $16.58 \pm 0.01$ & $2.91 \pm 0.006$ & $5.52 \pm 0.01$ & $13.77 \pm 0.02$ \\
\hline Mallika & $16.03 \pm 0.08$ & $4.00 \pm 0.05$ & $0.24 \pm 0.006$ & $17.53 \pm 0.02$ & $2.82 \pm 0.006$ & $6.05 \pm 0.01$ & $14.00 \pm 0.06$ \\
\hline Seedling mango & $13.26 \pm 0.14$ & $3.82 \pm 0.01$ & $0.31 \pm 0.006$ & $30.12 \pm 0.06$ & $1.57 \pm 0.017$ & $5.06 \pm 0.02$ & $12.42 \pm 0.02$ \\
\hline $\mathrm{CD}_{0.05}$ & 0.301 & 0.103 & 0.016 & 0.145 & 0.036 & 0.064 & 0.178 \\
\hline
\end{tabular}


Table.3 Effect of foaming agent concentrations on drying time (hours) of mango pulp of different cultivars

\begin{tabular}{|c|c|c|c|c|c|}
\hline \multirow{2}{*}{\multicolumn{2}{|c|}{$\mathrm{Cultivars}_{\text {Concentrations }}^{\text {Culions }}$}} & \multicolumn{4}{|c|}{ Drying time (hrs) } \\
\hline & & $0 \%$ & $1 \%$ & $2 \%$ & Mean \\
\hline \multicolumn{2}{|c|}{ Amrapali } & 8.32 & 7.87 & 7.51 & 7.90 \\
\hline \multicolumn{2}{|c|}{ Dashehari } & 8.25 & 7.54 & 7.45 & 7.75 \\
\hline \multicolumn{2}{|l|}{ Mallika } & 9.02 & 8.34 & 8.25 & 8.54 \\
\hline \multicolumn{2}{|c|}{ Seedling mang0 } & 8.34 & 8.09 & 7.48 & 7.97 \\
\hline \multicolumn{2}{|l|}{ Mean } & 8.48 & 7.96 & 7.67 & \\
\hline \multicolumn{6}{|l|}{$\mathrm{CD}_{0.05}$} \\
\hline & \multicolumn{2}{|l|}{ Cultivars (C) } & $=$ & 0.075 & \\
\hline & \multicolumn{2}{|c|}{ Foaming agent concentration $(F)$} & $=$ & 0.065 & \\
\hline & \multicolumn{2}{|l|}{$\mathbf{C} \times \mathbf{F}$} & $=$ & 0.129 & \\
\hline
\end{tabular}

Table.4 Effect of different concentrations of foaming agent (carboxy methyl cellulose) on powder yield of different cultivars of mango

\begin{tabular}{|c|c|c|c|c|c|}
\hline \multirow{2}{*}{\multicolumn{2}{|c|}{$\mathrm{Cultivars}_{\text {Concentrations }}^{\text {Cultions }}$}} & \multicolumn{4}{|c|}{ Yield (\%) } \\
\hline & & $0 \%$ & $1 \%$ & $2 \%$ & Mean \\
\hline \multicolumn{2}{|c|}{ Amrapali } & 14.80 & 14.91 & 15.05 & 14.92 \\
\hline \multicolumn{2}{|c|}{ Dashehari } & 14.76 & 14.85 & 15.01 & 14.87 \\
\hline \multicolumn{2}{|c|}{ Mallika } & 14.85 & 14.94 & 15.10 & 14.96 \\
\hline \multicolumn{2}{|c|}{ Seedling mang0 } & 13.72 & 13.85 & 14.23 & 13.93 \\
\hline \multicolumn{2}{|l|}{ Mean } & 14.53 & 14.64 & 14.84 & \\
\hline \multicolumn{6}{|l|}{$\mathrm{CD}_{0.05}$} \\
\hline & \multicolumn{2}{|l|}{ Cultivars (C) } & $=$ & 0.075 & \\
\hline & \multicolumn{2}{|c|}{ Foaming agent concentration $(F)$} & $=$ & 0.065 & \\
\hline & \multicolumn{2}{|l|}{$\mathbf{C} \times \mathbf{F}$} & $=$ & 0.130 & \\
\hline
\end{tabular}


Table.5 Effect of concentrations of foaming agent on TSS, pH and Titratable acidity of mango powder of different cultivars

\begin{tabular}{|c|c|c|c|c|c|c|c|c|c|c|c|c|c|c|}
\hline \multirow{2}{*}{\multicolumn{2}{|c|}{$\begin{array}{l}\text { Concentrations } \\
\text { Cultivars }\end{array}$}} & \multicolumn{5}{|c|}{ TSS $\left({ }^{0} \text { Brix }\right)^{*}$} & \multicolumn{4}{|c|}{ Titratable acidity (\%) } & \multicolumn{4}{|c|}{ pH } \\
\hline & & $0 \%$ & $1 \%$ & \multicolumn{2}{|c|}{$2 \%$} & Mean & $0 \%$ & $1 \%$ & $2 \%$ & Mean & $0 \%$ & $1 \%$ & $2 \%$ & Mean \\
\hline \multicolumn{2}{|c|}{ Amrapali } & 83.00 & 83.40 & \multicolumn{2}{|c|}{83.70} & 83.36 & 1.14 & 1.02 & 0.94 & 1.03 & 4.70 & 4.72 & 4.75 & 4.72 \\
\hline \multicolumn{2}{|c|}{ Dashehari } & 81.35 & 81.65 & \multicolumn{2}{|c|}{82.00} & 81.66 & 1.23 & 1.17 & 1.05 & 1.15 & 4.65 & 4.67 & 4.70 & 4.67 \\
\hline \multicolumn{2}{|c|}{ Mallika } & 81.70 & 82.00 & \multicolumn{2}{|c|}{82.40} & 82.03 & 1.13 & 1.05 & 0.95 & 1.04 & 4.72 & 4.76 & 4.79 & 4.75 \\
\hline \multicolumn{2}{|c|}{ Seedling mango } & 80.50 & 80.75 & \multicolumn{2}{|c|}{81.05} & 80.76 & 1.53 & 1.36 & 1.25 & 1.38 & 4.00 & 4.05 & 4.10 & 4.05 \\
\hline \multicolumn{2}{|l|}{ Mean } & 81.63 & 81.95 & \multicolumn{2}{|c|}{82.28} & & 1.26 & 1.15 & 1.05 & & 4.51 & 4.55 & 4.58 & \\
\hline \multicolumn{15}{|l|}{$\mathrm{CD}_{0.05}$} \\
\hline & \multicolumn{4}{|c|}{ Cultivars (C) } & $=$ & 0.098 & & & & 0.024 & & & & 0.050 \\
\hline & \multicolumn{4}{|c|}{ Foaming agent concentrations $(F)$} & $=$ & 0.085 & & & & 0.021 & & & & 0.043 \\
\hline & \multicolumn{4}{|c|}{$\mathbf{C} \times \mathbf{F}$} & $=$ & NS & & & & 0.042 & & & & NS \\
\hline
\end{tabular}

Note: *for estimation of TSS, $10 \mathrm{~g}$ of powder was diluted to $100 \mathrm{ml}$ and resultant value multiplied by factor of 10 .

Table.6 Effect of concentrations of foaming agent on Moisture content, Ash content and Total carotenoids of mango powder of different cultivars

\begin{tabular}{|c|c|c|c|c|c|c|c|c|c|c|c|c|c|c|}
\hline \multirow{2}{*}{\multicolumn{2}{|c|}{$\begin{array}{l}\text { Concentrations } \\
\text { Cultivars }\end{array}$}} & \multicolumn{5}{|c|}{ Moisture content (\%) } & \multicolumn{4}{|c|}{ Ash content (\%) } & \multicolumn{4}{|c|}{ Total Carotenoids (mg/100g) } \\
\hline & & $0 \%$ & $1 \%$ & & & Mean & $0 \%$ & $1 \%$ & $2 \%$ & Mean & $0 \%$ & $1 \%$ & $2 \%$ & Mean \\
\hline \multicolumn{2}{|c|}{ Amrapali } & 6.00 & 5.72 & & & 5.74 & 4.59 & 4.62 & 4.65 & 4.62 & 12.42 & 12.24 & 11.94 & 12.20 \\
\hline \multicolumn{2}{|c|}{ Dashehari } & 6.10 & 5.82 & & & 5.82 & 4.55 & 4.57 & 4.60 & 4.57 & 12.15 & 12.01 & 11.84 & 12.00 \\
\hline \multicolumn{2}{|c|}{ Mallika } & 6.19 & 5.88 & & & 5.93 & 4.56 & 4.58 & 4.63 & 4.59 & 12.49 & 12.20 & 11.96 & 12.22 \\
\hline \multicolumn{2}{|c|}{ Seedling mango } & 6.05 & 5.81 & & & 5.79 & 4.50 & 4.53 & 4.55 & 4.52 & 12.09 & 11.94 & 11.77 & 11.93 \\
\hline \multicolumn{2}{|c|}{ Mean } & 6.08 & 5.80 & & & & 4.55 & 4.57 & 4.61 & & 12.29 & 12.10 & 11.88 & \\
\hline \multicolumn{15}{|l|}{$\mathrm{CD}_{0.05}$} \\
\hline & \multicolumn{4}{|c|}{ Cultivars (C) } & $=$ & 0.062 & & & & 0.023 & & & & 0.061 \\
\hline & \multicolumn{4}{|c|}{ Foaming agent concentrations $(F)$} & $=$ & 0.054 & & & & 0.020 & & & & 0.053 \\
\hline & \multicolumn{4}{|c|}{$\mathbf{C} \times \mathbf{F}$} & $=$ & NS & & & & NS & & & & 0.105 \\
\hline
\end{tabular}


Table.7 Effect of concentrations of foaming agent on Ascorbic acid, Reducing sugar and Total sugar of mango powder of different cultivars

\begin{tabular}{|c|c|c|c|c|c|c|c|c|c|c|c|c|c|c|}
\hline \multirow{2}{*}{\multicolumn{2}{|c|}{$\begin{array}{l}\text { Concentrations } \\
\text { Cultivars }\end{array}$}} & \multicolumn{5}{|c|}{ Ascorbic acid (mg/100g) } & \multicolumn{4}{|c|}{ Reducing sugar $(\%)$} & \multicolumn{4}{|c|}{ Total sugar (\%) } \\
\hline & & $0 \%$ & $1 \%$ & \multicolumn{2}{|c|}{$2 \%$} & Mean & $0 \%$ & $1 \%$ & $2 \%$ & Mean & $0 \%$ & $1 \%$ & $2 \%$ & Mean \\
\hline \multicolumn{2}{|c|}{ Amrapali } & 25.05 & 24.91 & \multicolumn{2}{|c|}{24.85} & 24.93 & 47.20 & 48.00 & 48.62 & 47.94 & 77.40 & 79.00 & 80.05 & 78.82 \\
\hline \multicolumn{2}{|c|}{ Dashehari } & 23.82 & 23.77 & \multicolumn{2}{|c|}{23.62} & 23.73 & 42.05 & 42.97 & 43.14 & 42.72 & 75.40 & 77.00 & 79.50 & 77.30 \\
\hline \multicolumn{2}{|c|}{ Mallika } & 24.87 & 24.67 & \multicolumn{2}{|c|}{24.61} & 24.71 & 45.00 & 45.95 & 46.69 & 45.88 & 76.55 & 78.60 & 79.90 & 78.35 \\
\hline \multicolumn{2}{|c|}{ Seedling mango } & 35.36 & 35.28 & \multicolumn{2}{|c|}{35.17} & 35.27 & 40.95 & 41.55 & 42.62 & 41.71 & 73.99 & 75.50 & 77.75 & 75.74 \\
\hline \multicolumn{2}{|c|}{ Mean } & 27.27 & 27.16 & \multicolumn{2}{|c|}{27.06} & & 43.80 & 44.62 & 45.26 & & 75.83 & 77.52 & 79.30 & \\
\hline \multicolumn{15}{|l|}{$\mathrm{CD}_{0.05}$} \\
\hline & \multicolumn{4}{|c|}{ Cultivars $(\mathbf{C})$} & $=$ & 0.021 & & & & 0.044 & & & & 0.029 \\
\hline & \multicolumn{4}{|c|}{ Foaming agent concentrations $(F)$} & $=$ & 0.018 & & & & 0.038 & & & & 0.025 \\
\hline & \multicolumn{4}{|c|}{$\mathbf{C} \times \mathbf{F}$} & $=$ & 0.036 & & & & 0.077 & & & & 0.050 \\
\hline
\end{tabular}

Table.8 Sensory evaluation of (9-point hedonic scale) of mango fruit powders of different cultivars prepared by using different concentrations of foaming agent (carboxy methyl cellulose)

\begin{tabular}{|c|c|c|c|c|c|c|c|c|c|c|c|c|c|c|c|c|c|}
\hline \multirow{3}{*}{ Concentrations } & \multicolumn{17}{|c|}{ Sensory properties } \\
\hline & \multicolumn{5}{|c|}{ Colour } & \multicolumn{4}{|c|}{ Taste } & \multicolumn{4}{|c|}{ Aroma } & \multicolumn{4}{|c|}{ Overall acceptability } \\
\hline & $0 \%$ & $1 \%$ & 29 & & Mean & $0 \%$ & $1 \%$ & $2 \%$ & Mean & $0 \%$ & $1 \%$ & $2 \%$ & Mean & $0 \%$ & $1 \%$ & $2 \%$ & Mean \\
\hline Amrapali & 7.80 & 8.13 & 8.9 & & 8.28 & 8.10 & 8.47 & 8.67 & 8.41 & 7.97 & 8.50 & 8.77 & 8.41 & 7.95 & 8.36 & 8.77 & 8.36 \\
\hline Dashehari & 6.70 & 6.90 & 6.9 & & 6.86 & 7.00 & 7.13 & 7.27 & 7.13 & 7.03 & 7.17 & 7.40 & 7.20 & 6.91 & 7.06 & 7.21 & 7.06 \\
\hline Mallika & 6.97 & 7.17 & 7.4 & & 7.18 & 7.63 & 7.67 & 7.80 & 7.70 & 7.60 & 7.70 & 7.70 & 7.67 & 7.40 & 7.51 & 7.63 & 7.51 \\
\hline Seedling mango & 6.03 & 6.70 & 6.9 & 90 & 6.55 & 6.50 & 6.71 & 7.00 & 6.74 & 6.70 & 6.75 & 7.00 & 6.82 & 6.41 & 6.72 & 6.97 & 6.70 \\
\hline Mean & 6.88 & 7.23 & 7.5 & 54 & & 7.30 & 7.49 & 7.68 & & 7.33 & 7.53 & 7.72 & & 7.17 & 7.41 & 7.65 & \\
\hline \multicolumn{18}{|l|}{$\mathrm{CD}_{0.05}$} \\
\hline \multicolumn{4}{|c|}{ Cultivars $(\mathbf{C})$} & $=$ & 0.129 & & & & 0.085 & & & & 0.100 & & & & 0.216 \\
\hline \multicolumn{4}{|c|}{ Foaming agent concentrations $(F)$} & $=$ & 0.112 & & & & 0.074 & & & & 0.087 & & & & 0.187 \\
\hline \multicolumn{3}{|c|}{$\mathrm{C} \times \mathbf{F}$} & & $=$ & 0.224 & & & & 0.147 & & & & 0.174 & & & & NS \\
\hline
\end{tabular}


Figure.1 Flow chart for preparation of foam mat dried mango powders

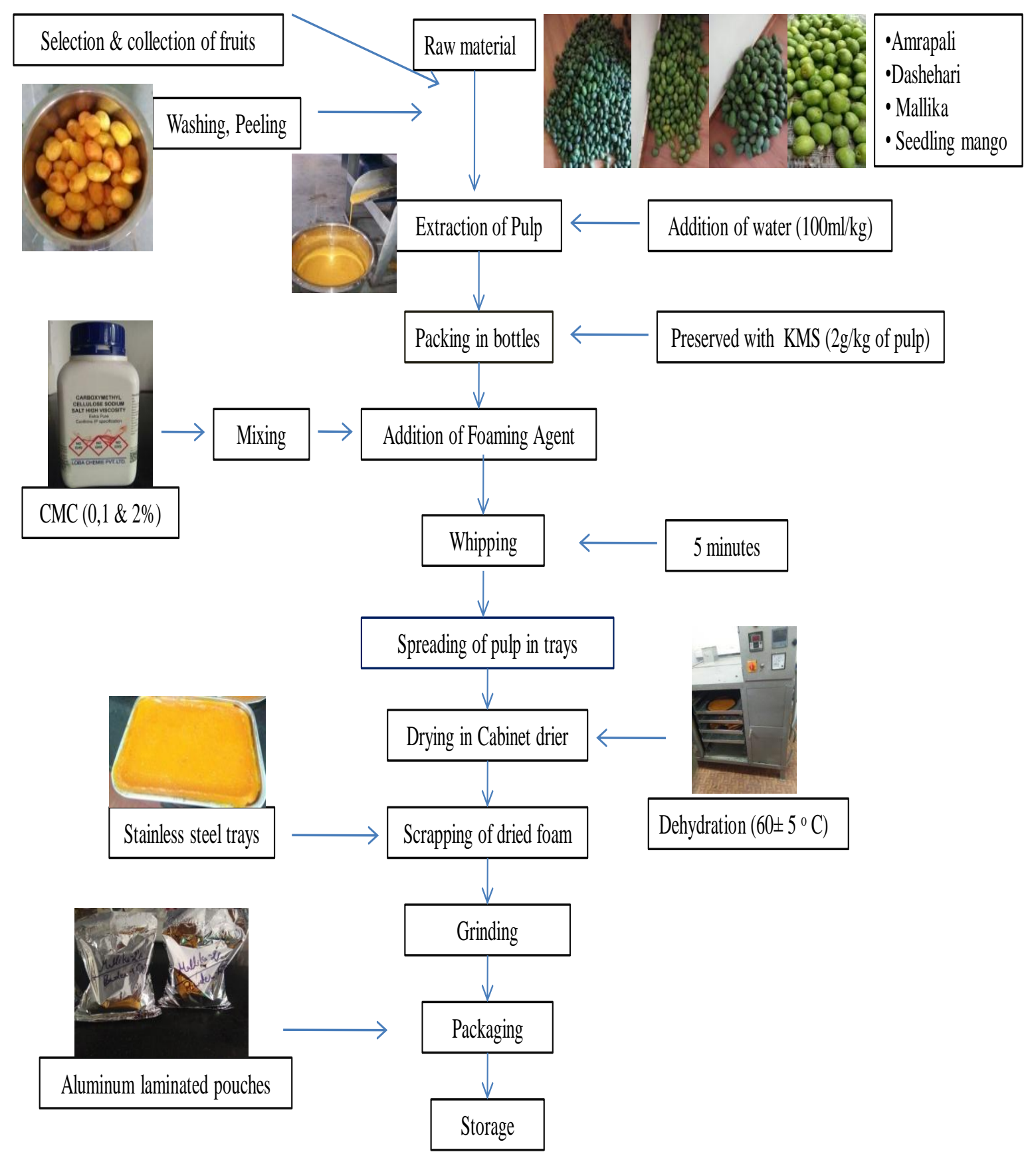



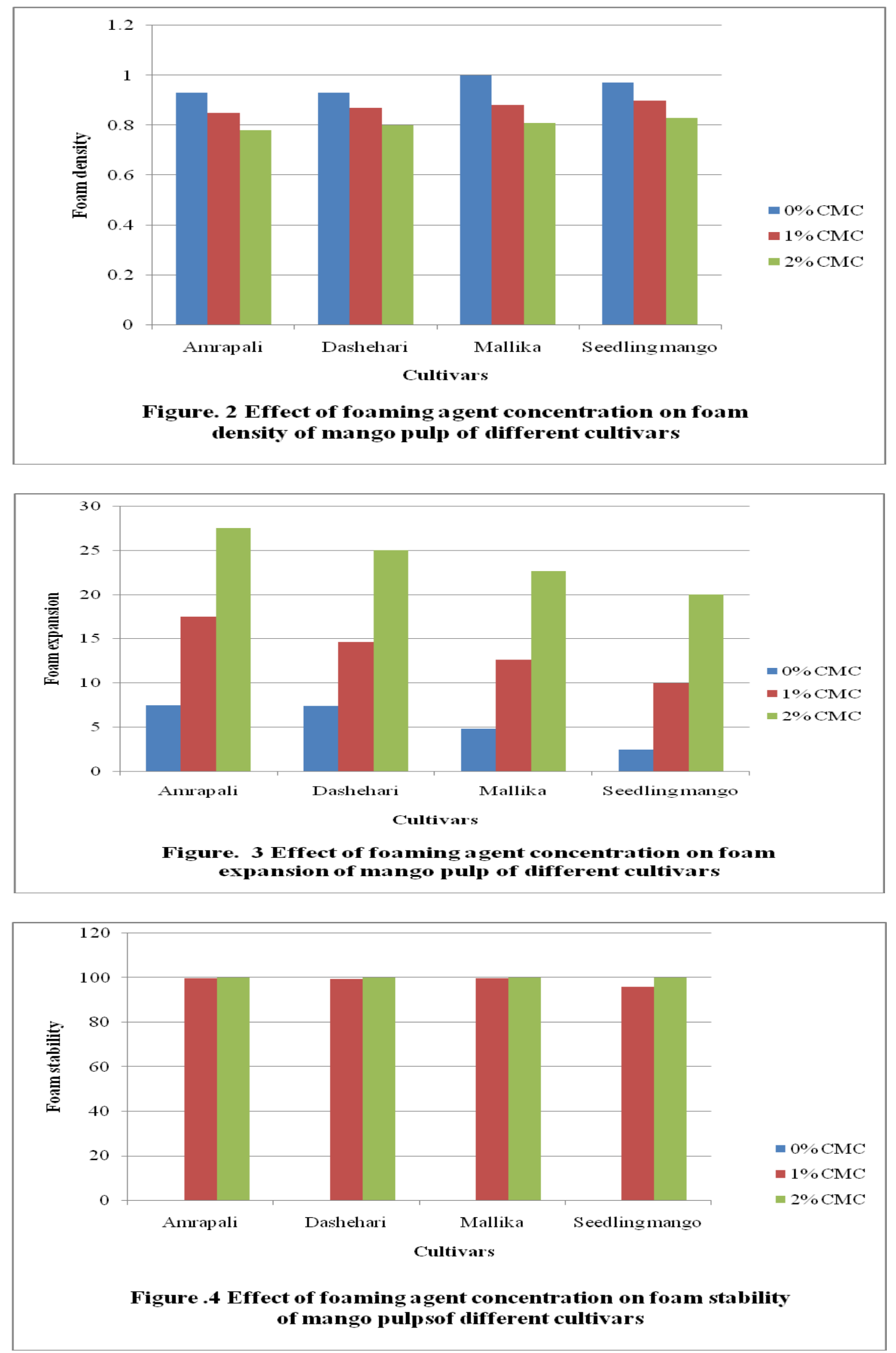
Earlier Chaves et al., (2013) recorded increase in sugar content of foam-mat Brazilian cherry pulp powder with the addition of foaming agent.

Sensory evaluation of mango powders of different cultivars prepared by using different concentrations of foaming agent (carboxy methyl cellulose)

Mango powder of different cultivars was evaluated for various sensory attributes on a 9 point hedonic scale. The data presented in Table 8 is discussed as under:-

\section{Colour}

The data recorded for mean colour score remained highly significant within all concentrations of CMC in different mango cultivars (Table 8). With an increase in concentrations of foaming agent, the colour acceptability of the mango powder exhibited increase on a 9 point hedonic scale ranging from 6.88 to 7.54. Among different cultivars colour score was recorded highest for Amrapali (8.28) and lowest for Seedling mangoes (6.55). Among different cultivars and concentrations of foaming agent, highest colour score (8.90) was recorded in cv. Amrapali with 2\% CMC and lowest in Seedling mango (6.03) without CMC.

\section{Taste}

Data presented in Table 8 shows that among different concentrations of foaming agent the mean taste score ranging from 7.30 to 7.68 . The taste acceptability is increased with an increase in concentrations of foaming agent. Among different cultivars the highest taste score was recorded in cv. Amrapali (8.41) and lowest in Seedling mango (6.74). Among different cultivars and concentration of foaming agent ranging from 6.50 to 8.67 and found significant for taste. Highest taste score
(8.67) was recorded in cv. Amrapali with $2 \%$ CMC and lowest in Seedling mango (6.50) without CMC.

\section{Aroma}

Aperusal of data in Table 8 shows that among different concentrations of foaming agent the mean aroma score ranging from 7.33 to 7.72. The aroma acceptability was observed to increased with an increase in concentrations of foaming agent. Among different cultivars the highest aroma score was recorded in cv. Amrapali (8.41) and lowest in Seedling mango (6.82). Among different cultivars and concentration of foaming agent the interaction was found significant for aroma ranging from 6.70 to 8.77. Highest aroma score (8.77) was recorded in cv. Amrapali with $2 \% \mathrm{CMC}$ and lowest in Seedling mango (6.70) without CMC. The interaction between cultivars and foaming agent found to be significant for aroma.

\section{Overall acceptability}

Data presented in Table 8 shows that among different concentrations of foaming agent the mean overall acceptability score ranging from 7.17 to 7.65. An increasing trend was obtained for overall acceptability with the increase in concentrations of foaming agent. Among different cultivars the highest overall acceptability score was recorded in $\mathrm{cv}$. Amrapali (8.36) and lowest in Seedling mango (6.70). Among different cultivars and concentrations of foaming agent highest overall acceptability score (8.77) was recorded in cv. Amrapali with $2 \% \mathrm{CMC}$ and lowest in Seedling mango (6.41) without CMC.

\section{References}

Affandi N, Zzaman W, Yang T A and EasaA M. 2017. Production of Nigella sativa 
beverage powder under foam mat drying using egg albumen as a foaming agent. Beverages 3(9): 1-15.

Akhter S, Abid H, Yasmin A and Masood S. 2010. Preparation and evaluation of physical and chemical characteristics of instant mango juice powder. Pakistan Journal of Biochemistry and Molecular Biology43(2): 58-60.

Akiokato A T, Matsudomi N and Kobayashi K. 1983. Determination of foaming properties of egg white by conductivity measurements. Journal of Food Science and Technology48(1): 62-65.

Amerine M A, Pangborn R M and Rossler E B. 1965. Principles of sensory evaluation of food. Academic Press, New York. p: 254.

AOAC. 1995. Official methods of analysis of association of official analytical chemists, $16^{\text {th }}$ edition. Vol. I and II. Association of Official Analytical Chemists, Arlington, Virginia, USA.

Ara R, Motalab M, Uddin M N, Fakhruddin A N M and Saha B. K. 2014. Nutritional evaluation of different mango varieties available in Bangladesh. International Food Research Journal 21(6): 21692174.

Badhe V T, Singh, Pratap, Powar A G and Bhaft Y C. 2007. Studies on physical properties of Alphanso mango. Agricultural Engineering Today, 31(1) 20-24.

Bains K S and Dhillon W S. 1999. Physicochemical characteristics of different mango (Mangifera indica L.) grown under submontaneous conditions of Punjab. Haryana Journal of Horticulture Science, 28(3 \& 4): 174176.

Barreto J C, Trevisan M T, Hull W E, Erben G, De Brito E S, Pfundstein B, Würtele $\mathrm{G}$, Spiegelhalder B and Owen $\mathrm{R} \mathrm{W}$. 2008. Characterization and quantitation of polyphenolic compounds in bark, kernel, leaves, and peel of mango (Mangifera indica L.). Journal of Agricultural and Food Chemistry56(14): 5599-5610

Chanana Y R, Josan J S and Arora P K. 2005. Evaluation of some mango cultivars under North India condition. International conference on Mango and Date Palm: Culture and Export. 20$23^{\text {rd june, 34-38. }}$

Chaves A M, Barreto M A I, Reis C R and Kadam M D. 2013. Physicochemical and sensory properties of purple Brazilian cherry (Eugenia uniflora, L.) foams. International Journal of Food Science and Technology48: 1688-1697.

Cochran W G and Cox C M. 1967. Experimental Designs. John Wiley and Sons, Inc. New York CRC Press, London, UK.

Danalache F, Paulina M and Martins M M. 2015. Texture, microstructure and consumer preference of mango bars jellified with gellan gum, LWT. Food Science and Technology 62: 584-591.

Falade F O, Adeyanju K I and Uzo-Peters P I. 2003. Foam mat drying of cowpea (Vigna unguiculata) using glyceryl monostearate and egg albumen as foaming agents. Food Research Technology, 217: 486-491.

Gowda D, Ambadan and Ramanjaneya KH. 1995. Studies on mango fruit bar preparation. Indian Food Packer, 49(2): 17-24.

Hada T S and Singh A K. 2018. Evaluation of mango (Mangifera indica L.) cultivars for physical characteristics and quality parameters of fruit under indo-gangetic plains. International Journal of Chemical Studies 6(2): 2560-2563.

Harshitha T, Rakesh G, Siddiqui $S$ and Rekha. 2016. Physico-chemical composition of fresh fruits of mango cultivars. Progressive Research - An International Journal, 11(2): 139-140. 
Hossain M M, Haque M A, Rahim M A and Rahman M H. 2001. Physicomorphological and composition variation in ripe fruit of three mango variety. Journal of Biological Science 1(11): 1101-1102.

Jha S N, Vishwakarma R K, Ahmad T, Rai A and Dixit A K. 2015. Report on assessment of quantitative harvest and post harvest losses of major crops and commodities in India. ICAR-All India Coordinated Research Project on PostHarvest Technology ICAR-CIPHET, PO:PAU, Ludhiana p: 73-78.

Jori D, Ladole M, Gore A and Bhand V .2013. Study on Effect of Carbonation on Storage and Stability of Pineapple Fruit Juice. International Journal of Engineering Research \& Technology2(12): 1841-1847.

Kadam D M, Rai D R, Patil R T, Wilson R A, Kaur S and Kumar R. 2011. Quality of fresh and stored foam mat dried mandarin powder. International Journal of Food Science and Technology46: 793-799.

Kandasamy P, Varadharaju N, Kalemullah S and Maladhi D. 2014. Optimization of process parameters for foam-mat drying of papaya pulp. Journal of Food Science and Technology 51(10): 2526-2534.

Khamjae T and Rojanakorn T. 2018. Foammat drying of passion fruit aril. International Journal of Food Research 25(1): 204-212.

Ladole M R, Muley A B, Patil I D, Talib M I and Parate V R .2014. Immobilization of Tropizyme-P on amino functionalized magnetic nanoparticles for fruit juice clarification. Journal of Biochemical Technology5(4): 838-845.

Mahony M O. 1985. Sensory evaluation of food: statistical methods and procedures. Marcel Dekker Inc., New York. 132.

Marinova K G, Basheva E S, Nenova B,
Temelska M, Mirarefi A Y, Campbell B and Ivanov I B. 2009. Physico-chemical factors controlling the formability and foam stability of milk proteins: Sodium caseinate and whey protein concentrates. Food Hydrocollides 37: 498-506.

Mishra P K, Pathak S, Singh R K, Sahay S, Tiwari D K, Shrivastava P and Rashmi K. 2014. Evaluation of mango (Mangifera indica) cultivars for preparation of osmo-dehydrated product. The Bioscan 9(4): 1495-1498.

Mitra S K and Baldwin E A. 1997. Mango. Postharvest physiology and storage of tropical and subtropical fruits. Wallingford, UK:CAB International $\mathrm{p}$ : 85-122.

Negi S S. 2000. Mango production in India. Acta Horticulture 509: 69-78.

NHB 2018. India Horticulture Database. National Horticultural Board, Ministry of Agriculture, Co-operation and Farmers Welfare Government of India, Gurgaon p: 189-278.

Patil V, Chauhan A K and Singh S P. 2014. Influence of spray drying technology on the physical and nutritional properties of guava powder. International Journal of Current Microbiology and Applied Sciences 3(9): 1224-1237.

Rajkumar P and Kailappan R. 2006. Optimizing the process parameters for foam mat drying of Totapuri mango pulp. Madras Agriculture Journal93(16): 86-98.

Rajkumar P, Kailappan R, Viswanathan R, Parvathi K and Raghavan G S V. 2007. Thin layer drying study on foamed mango pulp. International Journal of Commission of Agriculture and Biosystem Engineering p: 224-238.

Ranganna S. 2014. Handbook of Analysis and Quality Control for Fruit and Vegetable Products. Tata McGraw Hills Publishing Co. Ltd., New Delhi. 1- 
1112.

Rockwell W C, Lowe E, Morgan A I, Graham R P and Ginnette L F. 1962. Food Engineering 34(8): 86.

Safdar M N, Mumtaz A, Hameed T, Siddiqui N, Khali S and Amjad M. 2012. Storage studies of Jam Prepared from different mango varieties. Pakistan Journal of Nutrition 11: 555-561.

Shaari N A, Sulaiman R, Rahman R A and Bakar J. 2017. Production of pineapple fruit (Ananas comosus) powder using foam mat drying: effect of whipping time and egg albumen concentration. Journal of Food Processing and Preservation p: 1-10.

Shafique M Z, Ibrahim M, Heleli M O H and Biswas S K. 2006. Studies on the physiological and biochemical composition of different mango cultivars at various maturity levels. Bangladesh Journal of science and Indian Research41(1-2): 101-108.

Sharada S. 2013. Studies on effect of various operating parameters $\&$ foaming agentsDrying of fruits and vegetables. International Journal of Modern Engineering Research3(3): 1512-1519.

Sharma J N, Josan J S, Thins S K and Arora P K.1999. Evaluation of mango cultivars for arid irrigated region of Punjab. Journal of Applied Horticulture Lucknow 1(2): 103-104.

Sharma P C, Sharma S K and Kaushal B B. 2002. Studies on the preparation of foam mat dried hill lemon (Citrus pseudolimon Tan.) juice powder. Indian Food Packer 56(4): 67-71.

Sharma S K, Sharma P C and Kaushal B B L. 2004. Storage studies of foam mat dried hill lemon (Citrus pseudolimon Tan.) juice powder. Journal of Food Science and Technology41(1): 9-13.

Singh U R, Upadhyay N P and Tripathi B M. 1976. Physiological and biochemical changes during maturity of mangoNeelam. Progressive Horiculture8:1318.

Srinivasan N. 1996. Shelf life test design for dehydrated apple powder. Thesis, Departmet of Agriculture and Food Engineering, IIT, Kharagpur.

Vijayanand P, Deepu E and Kulkarni S G. 2015. Physico chemical characterization and the effect of processing on the quality characteristics of Sindura, Mallika and Totapuri mango cultivars. Journal of Food Science and Technology 52(2): 1047-1053.

Wilson R A, Kadam D M, Chadha S and Sharma M. 2012. Foam mat drying characteristics of mango pulp. International Journal of Food Science and Nutrition Engineering 2(4): 63-69.

Xess R, Tripathi A, Bhuarya M and Sahu D. 2018. Evaluation of physical and chemical composition of mango varieties for nectar and pana. International Journal of Current Microbiology and Applied Sciences 7(11): 2622-2627.

\section{How to cite this article:}

Namita Rani, Anil Kumar Verma, P.C. Sharma, Raj Saini and Shivani. 2020. Composition and Characterization of Foam Mat Dried Powder Prepared From Seedling and Cultivated Mango Cultivars of Himalayan Region. Int.J.Curr.Microbiol.App.Sci. 9(05): 593-611. doi: https://doi.org/10.20546/ijcmas.2020.905.067 